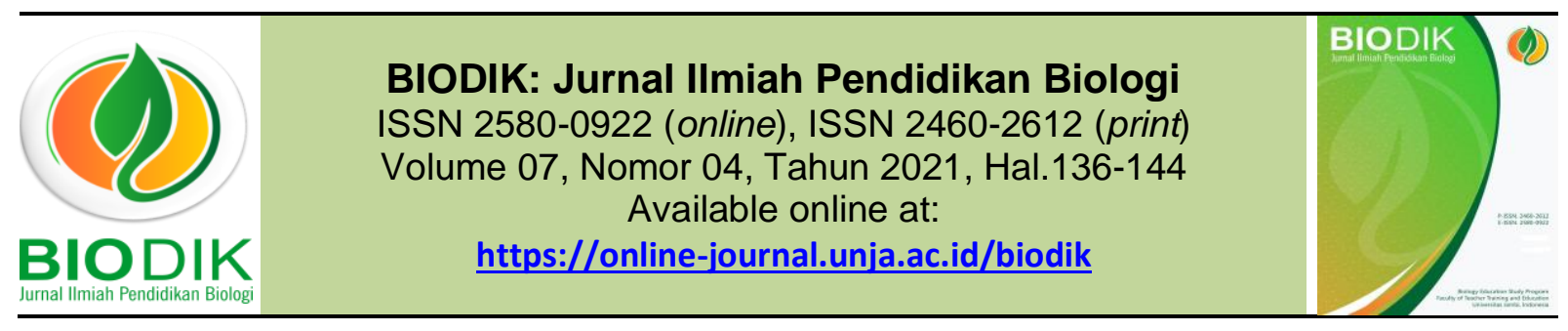

Research Article

\title{
Analisis Keterampilan Mengajar Guru IPA Pada Masa Pandemi Di SMP Islam Terpadu Se-Kota Palembang
}

\section{(Science Teacher Teaching Skills Analysis During the Pandemic Period at Integrated Islamic Middle Schools in Palembang City)}

Rohima*, Sri Wardhani, Astrid S.W. Sumah

Program Studi Pendidikan Biologi, Universitas Muhammadiyah Palembang

JI. Jendral Ahmad Yani, Kelurahan 13 Ulu, Kecamatan Seberang Ulu II, Kota Palembang, Sumatera Selatan 30263

*Corresponding Author: rizfarohima@gmail.com,bundarohima2021@gmail.com

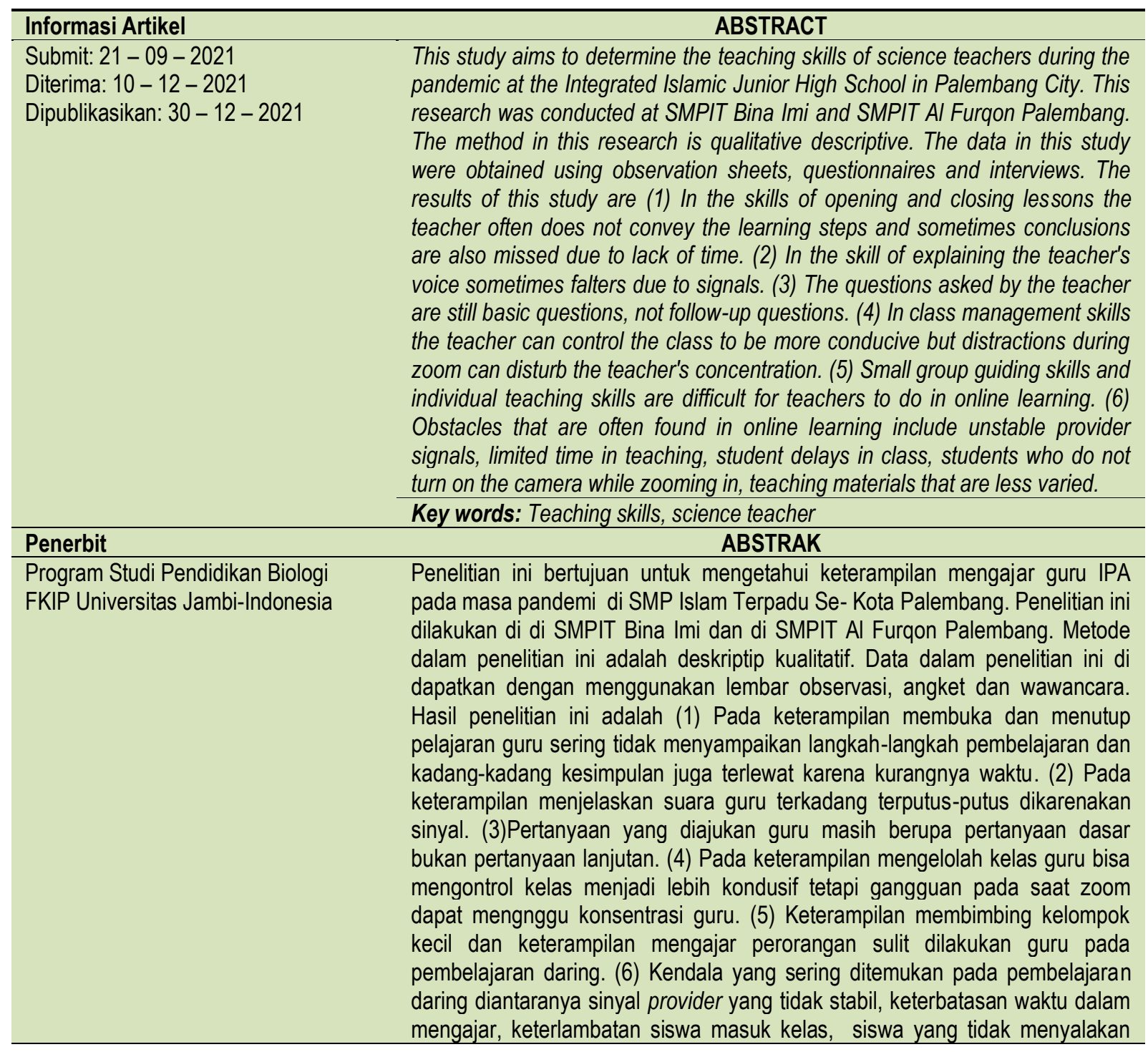


kamera saat zoom berlangsung, bahan ajar yang kurang bervariasi. kamera saat zoom berlangsung, bahan ajar yang kurang bervariasi.

Kata kunci: keterampilan mengajar, guru IPA

\section{(i) (2)}

BY NE SA

This BIODIK : Jurnal IImiah Pendidikan Biologi is licensed under a CC BY-NC-SA (Creative Commons Attribution-ShareAlike 4.0 International License)

\section{PENDAHULUAN}

Pendidikan merupakan salah satu faktor yang mendapat perhatian cukup serius di berbagai negara, baik negara maju maupun negara berkembang (Wardani, 2012:1) Hal ini dapat dimaklumi karena kenyataan menunjukkan bahwa pendidikan mempunyai peran penting dalam kemajuan satu negara. Keberhasilan suatu negara dalam mencetak generasi penerus yang cemerlang tidak terlepas dari peran seorang guru. Guru merupakan seseorang yang bertugas untuk mencetak sumber daya manusia yang berkualitas yang dapat bersaing hingga tingkat internasional. Guru memiliki peran penting untuk membuat peserta didik berkualitas baik akademis, keahlian, kematangan emosional, moral serta spiritual. Banyak pengorbanan yang telah diberikan oleh seorang guru semata-mata ingin melihat anak didiknya bisa berhasil dan sukses kelak. Tetapi perjuangan guru tersebut tidak berhenti sampai disitu, guru juga perlu meningkatkan kompetensi profesionalnya agar benar-benar menjadi guru yang lebih baik dan lebih profesional terutama dalam proses belajar mengajar sehari-hari.

Kompetensi merupakan hal yang esensial yang harus ada pada diri seorang guru. Undangundang No. 14 Tahun 2005 dan Peraturan Pemerintah No. 19 Tahun 2005 menyatakan bahwa, kompetensi guru meliputi kompetensi kepribadian, kompetensi pedagogik, kompetensi profesional, dan kompetensi sosial. Semua kompetensi tersebut harus dimiliki oleh seorang guru dalam melakukan kegiatan mengajar di sekolah (Dewi dkk, 2018:1).Kompetensi pedagogik adalah kemampuan mengelola pembelajaran peserta didik yang meliputi pemahaman terhadap peserta didik, perancangan dan pelaksanaan pembelajaran, evaluasi hasil belajar, dan pengembangan peserta didik untuk mengaktualisasikan berbagai potensi yang dimilikinya. Kompetensi pedagogik pada dasarnya adalah kemampuan guru dalam mengelola pembelajaran peserta didik (Helmi, 2015: 8).

Menurut Jupriyanto (2019:14) Keterampilan mengajar ialah kecakapan guru dalam menyajikan materi pelajaran antara lain, menguasai bahan pengajaran mampu memilih metode yang tepat dan penguasaan kelas dengan baik. Keterampilan tersebut tercermin dalam proses pembelajaran. Seorang guru harus memiliki keterampilan mengajar dalam melakukan pengajaran kepada siswa agar siswa dapat memahami pelajaran yang akan diajarkan. Oleh karena itu keterampilan mengajar guru sangatlah penting dalam proses pembelajaran.Guru dituntut untuk mampu melakukan pengajaran secara daring. Pada pembelajaran daring kemampuan guru dalam teknologi informasi sangat dibutuhkan. Pola mengajar pun juga mengalami perubahan. Pembelajaran secara daring guru harus siap dengan berbagai kondisi pembelajaran dan kondisi siswa, termasuk perkembangan kehidupan di masyarakat (Wahyono dkk, 2020: 2).

Perkembangan pada siswa meliputi tiga aspek yaitu kognitif, afektif, dan psikomotor. Tahaptahap perkembangan kemampuan kognitif manusia terbagi dalam beberapa fase. Pada tahap operasi formal fase ini dikenal juga dengan masa remaja. Remaja berpikir dengan cara lebih abstrak, logis, dan lebih idealistik. Tahap operasional formal, usia sebelas sampai lima belas tahun. Pada tahap ini individu sudah mulai memikirkan pengalaman konkret, dan memikirkannya secara lebih abstrak, idealis dan 
logis. Anak SMP rata rata usianya 11-15 tahun. Pada usia ini belum menunjukkan kematangan usia dan masih perlu bimbingan dan arahan orang dewasa yaitu guru, jadi anak-anak SMP masih sangat butuh pendampingan dari guru dalam belajar sehingga keterampilan mengajar guru sangat diperlukan.

\section{METODE PENELITIAN}

Metode dalam penelitian ini adalah deskriptip kualitatif. Strategi yang digunakan peneliti adalah studi kasus. Strategi ini digunakan untuk melihat kondisi yang lengkap dan mendalam mengenai keterampilan mengajar guru IPA di SMP Islam Terpadu di Kota Palembang.Penelitian Ini dialaksanakan pada Bulan Juli-Agustus 2021 di SMP Islam Terpadu yang ada di Kota Palembang yaitu Sekolah Islam Terpadu Bina IImi dan Al Furqon. Subjek penelitian ini adalah guru dan siswa dikelas 7 dan 8. Data dalam penelitian ini di dapatkan dengan menggunakan lembar observasi, angket, wawancara, dan dokumentasi. Data yang terkumpul pada penelitian ini adalah data kualitatif, sehingga teknik analisisnya sesuai dengan yang dikemukakan oleh Miles dan Huberman sebagaimana yang dikutip Sugiono (2001: 132-142) yaitu dilakukan secara interaktif, dengan reduksi data, sajian data, verifikasi data/penarikan kesimpulan.

\section{HASIL PENELITIAN DAN PEMBAHASAN}

Delapan indikator keterampilan mengajar guru seperti keterampilan membuka dan menutup pelajaran, keterampilan menjelaskan pelajaran, keterampilan bertanya, keterampilan mengadakan variasi, keterampilan mengelola kelas, keterampilan membimbing kelompok kecil, keterampilan memberi penguatan, dan keterampilan mengajar perorangan.

a. Keterampilan Membuka dan Menutup Pelajaran

Guru membuka pembelajaran dengan mengucapkan salam. Salam merupakan komponen pertama yang dilakukan guru sebagai bentuk sapaan kepada siswa. Semua guru melakukan memberikan salam saat membuka pembelajaran. Hasil penelitian ini sejalan dengan penelitian Yanti dkk (2016: 3) menyatakan bahwa keterampilan membuka pelajaran pengucapan salam sebagai bentuk pengakraban diri antara guru dan siswa.

Setelah salam guru memfokuskan kesiapan siswa dengan menanyakan materi sebelumnya dan mengintruksikan siswa untuk membuka kamera. Pada saat mengintruksikan membuka kamera masih ada siswa yang belum membuka sehingga guru menanyakan alasannya. Kesiapan siswa adalah bentuk semangat dalam mengikuti pelajaran. jika siswa semangat mengikuti pelajaran maka hasil belajar siswa juga akan menjadi lebih baik. Sejalan dengan hasil penelitian Darso (2011: 149) menyatakan bahwa kesiapan belajar siswa berpengaruh terhadap prestasi belajar.

Kegiatan pembelajaran dilanjutkan dengan apersepsi siswa yaitu dengan menanyakan materi yang telah dipelajari. Apersepsi adalah cara guru untuk melihat pemahaman siswa tentang materi yang telah dipelajari. Motivasi juga disampaikan guru dengan memberikan contoh manfaat mempelajari materi yang akan di bahas. sejalan dengan penelitian Inne ddk (2021: 7) semakin tinggi motivasi belajar maka akan berdampak pada Hasil Belajar.

Pada kegiatan menutup pelajaran guru berinisial DA dan RU tidak sempat menutup pelajaran dikarenakan waktu pembelajaran sudah selesai. Hal ini terjadi karena sinyal provider dan keterlambatan siswa saat memasuki kelas. saat melakukan wawancara, guru tersebut mejelaskan kendala pada sinyal provider sehingga kurangnya waktu saat menutup pelajaran. Padahal pada saat menutup pelajaran seharusnya guru memberikan kesimpulan terhadap apa yang telah mereka pelajari pada pembelajaran 
tersebut. Sejalan dengan penelitian Sani (2013: 6) Kegiatan menutup pelajaran mempengaruhi siswa dalam memahami materi yang diajarkan, karena akan membuat siswa memiliki konsep yang baik dari materi yang telah diajarkan oleh guru.

b. Keterampilan Menjelaskan Pelajaran

Pada saat menjelaskan pelajaran guru menggunakan bahasa yang baik dan benar, tetapi ada guru yang sesekali menjelaskan pelajaran dengan menggunakan bahasa daerah. Semua guru menjelaskan pelajaran sesuai dengan tujuan pembelajaran. saat menjelaskan, suara guru kadang terputus-putus saat sinyal provider mengalami gangguan. Guru bertindak cepat dengan mengecek kembali sinyal provider atau mengganti perangkat lain yang berbeda dari sebelumnya. Tetapi hal tersebut menganggu fokus guru jika terjadi cukup lama, kondisi tersebut akan merugikan guru karena waktu pelajaran ikut terpotong.

Penelitian ini sependapat dengan Asrul (2020:4) menyatakan bahwa kestabilan akses internet sangat berperan penting agar proses pembelajaran daring bisa berjalan dengan baik. Putria (2020: 10) juga berpendapat bahwa dalam pembelajaran daring kuota dan jaringan internet yang stabil menjadi faktor pendukung.

Guru dengan inisial $D$ menjelaskan pelajaran dengan menggunakan gerak tubuh sebagai tips dalam menghafal atau mengigat pelajaran. saat menjelaskan pelajaran guru juga menggunakan media pembelajaran seperti PPT dan video pembelajaran. tetapi video pembelajaran yang dipakai bersumber dari Youtube. Bukan hal asing lagi bahwa media pembelajaran digunakan sebagai alat bantu dalam proses belajar terutama saat menjelaskan pelajaran sehingga mempermudah siswa dalam menerima pelajaran. sejalan dengan hasil penelitian Nurrita (2018:171) media pembelajaran adalah alat yang membantu proses belajar mengajar sehingga pesan yang disampaikan menjadi lebih jelas dan tujuan pendidikan atau pembelajaran dapat tercapai dengan efektif dan efisien.

\section{c. Keterampilan Bertanya}

Pada saat melakukan pembelajaran semua guru mengajukan pertanyaan secara klasikal terlebih dulu. Jika tidak ada yang menjawab barulah guru mengajukan pertanyaan secara individu dan dilakukan secara acak atau bergilir. Pertanyaan yang diajukan oleh guru kebanyakan pertanyaan dasar dimana jawaban yang diberikan hanya ya tahu tidak. Tetapi ada satu guru yang mengajukan pertanyaan lanjutan dengan harapan siswa dapat menjawab pertanyaan lebih rinci dengan cara mengajukan pertanyaan pancingan. Sejalan dengan (Rusmayanti: 2017) bertanya tingkat lanjut lebih mengutamakan usaha untuk mengembangkan kemampuan berpikir siswa.

Setiap mengajukan pertanyaan ada waktu yang diberikan guru kepada siswa untuk menjawab pertanyaan walaupun waktu yang diberikan cukup singkat. Pertanyaan yang diajukan guru bertujuan untuk mengukur sejauh mana pemahaman siswa terhadap materi yang telah disampaikan. Kemampuan dalam menyusun pertanyaan perlu dikuasi oleh guru, berdasarkan hasil observasi metode tanya jawab sering digunakan pada pembelajaran daring. Ketika mengajukan pertanyan maka ada interaksi yang terjadi antara guru dan siswa. Sejalan dengan hasil penelitian Ayu dkk (2015: 7) keberhasilan proses pembelajaran sangat dipengaruhi oleh kesinambungan komunikasi (interaksi) antara guru dan siswa melalui bertanya.

\section{d. Keterampilan Mengadakan Variasi}

Keterampilan mengadakan variasi posisi selama belajar di masa pendemi posisi guru sulit untuk dilakukan. Posisi yang dimaksud disini adalah posisi tubuh guru di dalam mengajar yang tidak berpindah tempat dari sisi yang satu ke sisi yang lain di dalam kelas. Metode ceramah dan tanya jawab 
lebih sering dipakai selama mengajar pada masa pandemi. Sejalan degan penelitian Andin (2020:3) penggunaan metode ceramah salah satunya dapat menghemat waktu sehingga pada masa pandemi (pembelajaran online) seperti saat ini metode ceramah menjadi jalan utamanya dalam menyampaikan materi pembelajaran.

Penggunaan media zoom, edmodo, google calssroom, dan youtube menjadi pilihan selama belajar online (daring). Penggunaan ppt yang paling sering dipakai selain video pembelajaran. Peneliti menemukan ada satu guru yang menjadikan kolom chat zoom sebagai pengganti papan tulis saat menjelaskan disaat media ppt mengalami kendala. Sejalan dengan penelitian Zulfikar (2020:2) banyak tersedia aplikasi yang menyediakan fasilitas video conference untuk membantu proses pembelajaran, aplikasi atau media yang saat ini banyak digunakan oleh sekolah adalah aplikasi Zoom.

Berdasarkan hasil wawancara yang dilakukan dengan guru berinisial $D$ selama pembelajaran daring kendala yang ia hadapi adalah ketika ia harus mengajar materi sistem rangka tetapi anak-anak tidak bisa melihat contoh bendanya secara langsung. Anak cenderung cepat mengerti jika mereka melihat benda secara nyata.

\section{e. Keterampilan Mengelolah Kelas}

Setelah masuk ke ruang zoom guru menanyakan kesiapan belajar siswa sebelum pelajaran dimulai dengan memberikan arahan untuk membuka kamera, hal ini dilakukan guru untuk memantau kondisi siswa sebelum belajar dimulai. Jika terdapat siswa yang tiba-tiba mematikan kameranya guru akan menegur siswa untuk menyalakan kembali kecuali izin ke toilet. Kondisi ini sebenarnya cukup menganggu konsentrasi guru ataupu siswa lainnya.

Sejalan dengan penelitian Savira (2020:3) hal yang dapat dilakukan saat mengelola kelas yaitu guru harus merespon secara positif, menyajikan pembelajaran yang terencana dan efektif dalam keterbatasan waktu. Hal ini bisa dilakukan dengan mempersiapkan skenario pembelajaran dan mengatur, pembelajaran siswa menjadi serba terbatas dalam berkomunikasi, berinteraksi, dan berkreasi, sehingga siswa harus mampu beradaptasi dengan hal-hal yang baru, dan mendorong kolaborasi antara orang tua dan pihak sekolah. Saat melakukan wawancara dengan guru berinisial $\mathrm{C}$ dan $\mathrm{B}$, kendala yang yang sering mereka temui dalam mengelolah kelas adalah pada saat sinyal provider mengalami gangguan dan siswa yang datang terlambat, hal tersebut membuat kelas menjadi terganggu.

\section{f. Keterampilan Membimbing Kelompok Kecil}

Pada masa pandemi guru jarang melakukan diskusi kelompok kecil dikarenakan waktu yang tidak memungkinkan, guru cukup kerepotan harus membuat ruang diskusi setiap kelompok. Hal itu juga akan mempersulit guru dalam memantau sejauh mana diskusi mereka berjalan. tetapi ada juga guru yang masih melakukan diskusi tetapi diskusi yang dilakuan bukan diskusi dengan anggota kelompok sesama siswa tetapi diskusi yang dilakukan guru dengan menanyakan permasalahan yang nantinya diarahkan semua siswa untuk berpartisipasi dengan rentang waktu yang singkat.

Sejalan dengan penelitian Safitri (2014:3) hambatan yang ditemui guru ketika membimbing diskusi kelompok kecil berasal dari faktor guru, siswa, dan waktu. Saat melakukan wawancara dengan guru berinisial $B$ dan $D$, mereka tidak dapat menjalankan kegiatan diskusi selama pembelajaran daring. Hal ini disebabkan karena keterbatasan waktu yang yang akan digunakan.

\section{g. Keterampilan Memberikan Penguatan}

Keterampilan penguatan yang digunakan guru selama pembelajaran daring adalah penguatan dalam bentuk verbal dan non verbal. Penguatan verbal dilakukan guru dengan memberikan kata-kata 
pujian seperti bagus, pintar, tepat sekali, dan ya. Selain kata pujian guru juga memberikan penguatan noverbal berupa ancungan jempol, senyuman, dan anggukan kepala. Ada guru yang melakukan penguatan verbal dan non verbal secara bersamaan seperti pujian kata bagus diikuti ancungan jempol. Hasil penelitian ini sejalan dengan penelitian Agustina (2020: 1) penguatan verbal yang diterapkan dengan menggunakan kata-kata dan kalimat.

h. Keterampilan mengajar perorangan

Keterampilan mengajar perorangan sulit dikontrol saat kelas online berlangsung, hal ini disebabkan guru sulit memantau sejauh mana pemahaman siswa secara keseluruhan. Siswa yang memiliki karakter pendiam tidak dapat dipantau sejauh mana pemahamannya. Penelitian ini sejalan dengan Sri (2021:4) guru tidak bisa mengontrol para siswa secara menyeluruh, terlebih lagi saat pembelajaran menggunakan video conference.

Keterampilan perorangan hanya dapat dilakukan guru dengan menunjukkan sikap bersahabat atau memberi kenyamanan saat mengikuti kelas online. Berdasarkan penelitian Rohmayanti (2019:3) dalam pelaksanaan pembelajaran perorangan guru menyiapkan lingkungan belajar, dengan cara guru selalu menjaga situasi di dalam kelas saat belajar menjadi nyaman sehingga siswa tidak akan terganggu untuk mengikuti proses belajar dalam kelas. Pada saat wawancara dengan semua guru yang bersangkutan, mengajar perorangan tidak dapat dilakukan.

\section{SIMPULAN}

Pada keterampilan membuka dan menutup pelajaran guru sering tidak menyampaikan langkah-langkah pembelajaran dan kadang-kadang kesimpulan juga terlewat karena kurangnya waktu. Pada keterampilan menjelaskan suara guru terkadang terputus-putus dikarenakan sinyal. Pertanyaan yang diajukan guru masih berupa pertanyaan dasar bukan pertanyaan lanjutan. Pada keterampilan mengelolah kelas guru bisa mengontrol kelas menjadi lebih kondusif tetapi gangguan pada saat zoom dapat mengnggu konsentrasi guru. Keterampilan membimbing kelompok kecil dan keterampilan mengajar perorangan sulit dilakukan guru pada pembelajaran daring. Kendala yang sering ditemukan pada pembelajaran daring diantaranya sinyal provider yang tidak stabil, keterbatasan waktu dalam mengajar, keterlambatan siswa masuk kelas, siswa yang tidak menyalakan kamera saat zoom berlangsung, bahan ajar yang kurang bervariasi.

\section{UCAPAN TERIMA KASIH}

Terimakasih kepada semua dosen pembimbing, pihak sekolah dan siswa yang terlibat dalam penelitian, teman-teman yang selalu mensuport dan para staf kampus yang selalu oke, serta semua pihak yang terlibat baik secara langsung atau tidak langsung.

\section{RUJUKAN}

Ananda Rusydi. 2018. Profesi Pendidikan dan Tenaga Kependidikan. Medan: Lembaga Peduli Pengembangan Pendidikan Indonesia (LPPPI).

Andin, Pratiwi Retno 2020. Penerapan Metode Ceramah dan Diskusi Selama Pembelajaran Online. Universitas Riau, 2(3): 6.

Anngito, Albi dan Johan Setiawan. 2018. Metode Penelitian Kualitatif. 
Ayu Hana Indah Cahyani, Putu dkk. 2015. Analisis Keterampilan Bertanya Guru Dan Siswa Dalam Pembelajaran Bahasa Indonesia Di Kelas X TAV 1 SMK NEGERI 3 Singaraja. Jurnal Universitas Pendidikan Ganesha, 3(1):

Arifmiboy. 2019. Microteaching. Jawa Timur: Wade Group.

Asrul. 2020. Kendala Siswa Dalam Proses Pembelajaran Daring Selama Pandemi Covid-19 Di SMPN Satap 1 Ladongi. Universitas Muhammadiyah Kendari, 3 (2): 2.

Agustina. 2020. Keterampilan Guru Memberi Penguatan Dalam Pembelajaran Bahasa Indonesia Kelas X IPA Di SMA Negeri 1 Kota Bengkulu. Jurnal Ilmiah Korpus, 4(1).

Bastian. 2019. Analisis Keterampilan Dasar Mengajar Guru Dalam Melaksanakan Pembelajaran Di Sekolah Dasar. Pendidikan dan Pengajaran, 3(6): 4.

Cahyani Inne. 2021. Pengaruh Pembelajaran Jarak Jauh Dan Motivasi Belajar Peserta Didik Terhadap Hasil Belajar Seni Budaya Di Kelas IX SMP Negeri 1 Ciampea Kabupaten Bogor. Educate jurnal teknologi pendidikan, 2(1):7.

Darso. 2011. Kesiapan Belajar Siswa dan Interaksi Belajar Mengajar Terhadap Prestasi Belajar. Invotec, 7 (2): 149.

Dewi Ratika Sari, Taufani C. Kurniaitun dan Abubakar. 2018. Kemampuan Profesional Guru Dan Motivasi Kerja Terhadap Kinerja Mengajar Guru Sekolah Dasar. Jurnal Administrasi Pendidikan, 25 (1): 1.

Fitriyani, Yani dkk. Motivasi Belajar Mahasiswa Pada Pembelajaran Daring Selama Pandemik Covid-19. Jurnal Kependidikan, 6 (2):2.

Hanun Farida. 2015. Model Penyelenggaraan Pendidikan Sekolah Islam Terpadu (Studi Kasus Di SDIT Al-Biruni Makassar). Dialog, 38 (2): 4.

Hasanah Nurafifa, Mahmud Alpusari, dan Otang Kurniaman. 2017. Analisis Keterampilan Dasar Mengajar Guru Pada Proses Pembelajaran IPA Kelas V Sdn 11 Kecamatan Limapuluh Pekanbaru. Jurnal Online Mahasiswa, 4(1):10.

Helmiati. 2013. Micro Teaching. Yogyakarta: Aswaja Pressindo.

Helmi Jhon. 2015. Kompetensi Profesionalisme Guru. Al-Ishlah, 7(2): 8.

Ika Handarini, Oktafia. 2020. Pembelajaran Daring Sebagai Upaya Study From Home (SFH) Selama Pandemi Covid 19. Jurnal Pendidikan Administrasi Perkantoran (JPAP), 8 (3):7.

Jannah Widia Nur, Yuli Widiyono dan Ruganda. 2019. Analisis Ketrampilan Dasar Mengajar Mahasiswa PGSD Melalui Medote Simulasi. Prosiding Seminar Nasional Pascasarjana UNNES, 2(1): 8.

Jupriyanto dan Nuridin. 2019. Pengaruh Keterampilan Mengajar Guru Terhadap Aktivitas Belajar Siswa SD Negeri 04 Loning. Jurnal Pendidikan Dasar Indonesia, 4(1):14-18.

Khairiyah Mar'ah, Nur. 2020. Perubahan Proses Pembelajaran Daring Pada Siswa Sekolah Dasar di Tengah Pandemi Covid-19. Prosiding Seminar Nasional Pascasarjana UNNES. 
Kristiana Dini dan A. Muhibbin. 2018. Keterampilan Dasar Mengajar Dalam Pembelajaran matematika Di SMP. Jurnal Managemen Pendidikan, 13 (2): 2

Marpaung Josephine Natasha dan Wiputra Cendana. 2020. Keterampilan Menjelaskan Guru Untuk Membangun Minat Keterlibatan Siswa Dalam Pembelajaran Online. Jurnal Inovasi Pendidikan, 1(7): 7.

Nurrita, Teni. 2018. Pengembangan Media Pembelajaran Untuk Meningkatkan Hasil Belajar Siswa. Misykat, 3 (1) 171.

Parwathi Putu Lidya Suky, Nyomanm Santiyadnya, dan Agus Adiarta. 2017. Keterampilan Guru Dalam Mengelola Kelas Pada Pembelajaran Prakarya Dan Kewirausahaan Di SMA Negeri 1 Singaraja. Jurnal Pendidikan Teknologi dan Kejuruan, 14(2): 2.

Putria Hilna. 2020. Analisis Proses Pembelajaran Dalam Jaringan (DARING) Masa Pandemi Covid-19 pada Guru Sekolah Dasar. Jurnal Basicedu, 4 (4): 5.

Rojii Mohamad dkk. 2019. Desain Kurikulum Sekolah Islam Terpadu. Jurnal Manajemen Pendidikan Islam, 2(3): 1-12.

Rohmayanti. 2019. Pelaksanaan Pembelajaran Kelompok Kecil Dan Perorangan Pada Mata Pelajaran Bahasa Indonesia Siswa Kelas X Di SMA Negeri 8 Kota Bengkulu. Jurnal IImiah Korpus, 3(1): 3.

Rusmayanti Arida, Arju Muti'ah dan Furoidatul Husniah. 2017. Penerapan Keterampilan Bertanya dan Memberikan Penguatan dalam Pembelajaran Bahasa Indonesia di Kelas VII SMP Negeri 4 Jember. Lingua Franca, 2(2):1-7.

Safitri Eka dan Uep Tatang Sontani. 2016. Keterampilan Mengajar Guru Dan Motivasi Belajar Siswa Sebagai Determinan Terhadap Hasil Belajar. Jurnal Pendidikan Manajemen Perkantoran, 1(1): 8.

Safitri Merry, Gede Gunatama dan Ida Ayu Made Darmayanti. 2014. Keterampilan Membimbing Diskusi Kelompok Kecil Oleh Guru Bahasa Indonesia Di Kelas VII SMP Laboratorium Undiksha. Pendidikan Bahasa dan Sastra Indonesia, 2(1) :6.

Safitri. 2014. Keterampilan Membimbing Diskusi Kelompok Kecil Oleh Guru Bahasa Indonesia Di Kelas VII SMP Laboratorium Undiksha. Pendidikan Bahasa dan Sastra Indonesia, 2(1): 3.

Sani, Martina. 2013. Kegiatan Menutup Pelajaran. ABE 2(2): 6.

Savira, Alifia Annisa. 2020. Pengelolaan Kelas Secara Daring Di Masa Pandemi Pada Murid Kelompok Bermain. Insan jurnal psikologi dan kesehatan mental, 1(10):4.

Sihotang Hotmaulina dan Sahat T. Simorangkir. 2020. Pedoman Praktik Microteaching. Jakarta: UKI Press.

Sri Wahyuningsih Kompyang. 2021. Problematika Pembelajaran Daring Di Masa Pandemi Covid-19 Di SMA Dharma Praja Denpasar. Pangkaja, 24(1):4.

Subakti Hani dan Eka Selvi Handayani. 2021. Analisis Keterampilan Mengajar Guru Dalam Pembelajaran Bahasa Indonesia Daring Pada Siswa Sekolah Dasar. Diglosia, 5(1): 7-9.

Suendarti Mamik dan Witri Lestari. 2020. Kemampuan Keterampilan Dasar Mengajar Guru MIPA dalam Pembelajaran Kurikulum 2013. Jurnal IImiah Multi Sciences, 12 (2): 5 
Sugiono. 2021. Metode Penelitian Klualitatif. Bandung: Alfabeta.

Sumiah Nani, Aminuyati, F.Y. Khosmas. 2013. Analisis Keterampilan Mengajar Guru Dalam Meningkatkan Hasil Belajar Pada Mata Pelajaran Ekonomi Di SMA. Jurnal pendidikan dan pembelajaran khatulistiwa, 2 (9): 12.

Sundari Fitri Siti dan Yuli Muliyawati. 2017. Analisis Keterampilan Dasar Mengajar Mahasiswa PGSD. Pedagona, 1(1): 2.

Supriatna Eka dan Muhammad Arif Wahyupurnomo. 2015. Keterampilan Guru Dalam Membuka Dan Menutup Pelajaran Pendidikan Jasmani Olahraga Dan Kesehatan Di SMAN Se-Kota Pontianak. Jurnal Pendidikan Jasmani Indonesia, 11 (1): 2

Susanti Anik dan Nugrananda Janattaka. 2020. Analisis Keterampilan Guru Dalam Mengadakan Variasi Pembelajaran Tematik Kelas 1 SDN 1 Gondang Kabupaten Tulungagung. Didika, 6(1):2.

Suyatno. 2015. Sekolah Islam Terpadu Dalam Sistem Pendidikan Nasional. Al-Qalam, 21 (1):4.

Undang-Undang Republik Indonesia nomor 14 tahun 2005 tentang guru dan dosen. (2005). Jakarta: Departemen Pendidikan Nasional.

Wahyono Poncojari dkk. 2020. Guru profesional di masa pandemi Covid-19: Review Implementasi, Tantangan, dan Solusi Pembelajaran Daring. Jurnal Pendidikan Profesi Guru, 1(1): 2.

Wardani I G. A. K. 2012. Mengembangkan Profesionalisme Pendidik Guru. Jurnal Pendidikan, 13 (1): 33

Wedyawati Nelly. 2015. Deskripsi Analisis Keterampilan Variasi Mengajar Guru IPA Di Sekolah Dasar Negeri 12 Jerora Sintang. Vox Edukasi, 6 (2): 9.

Yanti Lisa, Nurul Afifah dan Enny Afniyanti. 2016. Analisis Keterampilan Mengajar Guru IPA Di MTsThamrin Yahya Kecamatan Rambah Hilir Kabupaten Rokan Hulu Tahun Pembelajaran 2015/2016. Universitas Pasir Pengaraian, 2(1): 2-8.

Zulfikar 2020. Efektifitas Penggunaan Media Zoom Terhadap Pembelajaran Pada Masa Pandemi Covid-19. Pranata Edu. 2(1):2. 